\title{
Virulence Gene Characterization and Serotyping of Major Bacterial Pathogens Isolated from Bovine Respiratory Disease in Ethiopia
}

\section{Mirtneh Akalu1,2,* $(0$, Takele Abayneh², Esayas Gelaye², Getaw Derese², Behailu Tefera², Teferi Degefa ${ }^{2}$, Vemulapati Bhadra Murthy ${ }^{1}$}

${ }^{1}$ Koneru Lakshmaiah Education Foundation, Department of Biotechnology, Vaddeswaram, Gunture, India

${ }^{2}$ National Veterinary Institute, Bishoftu, Ethiopia

Email: *mirtneh2010@gmail.com

How to cite this paper: Akalu, M., Abayneh, T., Gelaye, E., Derese, G., Tefera, B., Degefa, T. and Murthy, V.B. (2022) Virulence Gene Characterization and Serotyping of Major Bacterial Pathogens Isolated from Bovine Respiratory Disease in Ethiopia. Advances in Microbiology, 12, 10-24. https://doi.org/10.4236/aim.2022.121002

Received: December 23, 2021

Accepted: January 22, 2022

Published: January 25, 2022

Copyright $\odot 2022$ by author(s) and Scientific Research Publishing Inc. This work is licensed under the Creative Commons Attribution International License (CC BY 4.0).

http://creativecommons.org/licenses/by/4.0/

\begin{abstract}
Bovine Respiratory Disease (BRD) causes a severe form of pneumonia in all age of cattle. This study was designed to investigate the distribution of capsular types, serotypes, and virulence-associated genes of the major bacterial pathogens from BRD outbreak samples in Ethiopia. In this study 166 samples were collected from clinically sick $(n=107)$ and pneumonic lung tissue $(n=59)$. Laboratory assay confirmed isolation of M. haemolytica 37 (22.29\%), P. multocida 25 (15.06\%), B. trehalosi 12 (7.23\%), and H. somni 15 (9.04\%). PCR assay of $P$. multocida capsular typing revealed 21 (84.0\%) cap A (hyaD-hyaC) and $4(16.0 \%)$ cap D $(d c b F)$ strains. M. haemolytica serotypes belonged to A: 1, A: 2, and A: 6 from 26 (70.27\%), 4 (10.81\%), and 7 (18.92\%) isolates, respectively. P. multocida biotyping showed isolation of A: 1, A: 2, and A: 3 from 3 (14.29\%), 2 (9.52\%), and 16 (76.19\%) isolates, respectively. M. haemolytica harbored more than $60 \%$ ssa gene, and $90.91 \%$ $\operatorname{sod} A$ while $F b p A, T b p A$, and $l k t C$ genes were found in all isolates. Likewise, all $P$. multocida exhibited tox $A, F b p A, T b p A$, and $p m S L P$ genes. The current finding showed that $M$. haemolytica serotype A: 1 is frequently associated with BRD followed by $P$. multocida biotype A: 3 . These two isolates harbored diverse virulence-associated genes and presented the pathogenic potential of the current isolates. Thus, investigation of pathogenic strains of $\mathrm{BRD}$, virulence genes distribution, and molecular epidemiology of the disease from wider areas of the country are essential. Hence, continuous outbreak surveillance and molecular approaches are indispensable in designing efficient prevention strategies.
\end{abstract}




\section{Keywords}

BRD, M. haemolytica, P. multocida, Serotypes, Virulence Genes

\section{Introduction}

Ethiopia has the largest number of livestock in Africa and home for various animal species. The country is naturally endowed with different agro-ecological zones and suitable for livestock production. Cattle are the most important livestock subsector in the country and the main providers of nutrition and income for livelihoods. The total cattle population in the country is estimated to be 59.5 million and distributed evenly throughout the country, with higher density in the highland areas [1] [2]. However, the productivity potential remained very low to meet the growing demand of the population. This is due to various constraints such as high prevalence of veterinary disease, low animal health service coverage, and shortage of access to inputs. Moreover, animal health issues are the major barriers to productivity. Prevalence of veterinary important diseases like respiratory illness exert negative impact on productivity and contributes to economic losses in the country [3] [4].

BRD is considered as one of the potential disease in all age of cattle [5] [6]. BRD is caused by diverse bacterial pathogens including Pasteurella multocida ( $P$. multocida), Mannheimia haemolytica (M. haemolytica), Histophilus somni ( $H$. somni), Mycoplasma species, and Trueperella Pyogens (T. pyogens) [7] [8]. Acute infection can be caused by virulent strains of $M$. haemolytica, $P$. multocida, and H. somni. These pathogens are opportunistic, possess different virulence genes, and are capable of infecting the lower airway and lung parenchyma [7] [9] [10]. Moreover, $M$. haemolytica and $H$. somni do not constantly involve stressors (environmental and management) or other concomitant infections to cause fatal pneumonia [7].

Strains of $M$. haemolytica can be classified into 17 serotypes using indirect haemagglutination assay of the capsular polysaccharide antigen. 12 serotypes belong to biotype A $(1,2,5,6,7,8,9,12,13,14,16$, and 17) and are reclassified as $M$. haemolytica. 4 serotypes belong to biotype $\mathrm{T}(3,4,10$, and 15) and are worth mentioned as $B$. trehalosi, while $M$. glucosida was belonged to serotype A: 11 [11] [12]. P. multocida was grouped into five capsular types (A, B, D, E, and F) based on cap loci variation and characterized using primers designed for polymerase chain reaction (PCR) assay [13] [14]. Besides, P. multocida was further classified based on its lipopolysaccharide (LPS) into eight LPS (L1 - L8) genotypes [15].

$M$. haemolytica and $P$. multocida possess a range of virulence factors that influence the host defense mechanism and enable colonization and infection [15]. M. haemolytica pathogenicity is associated with various virulence factors of outer membrane proteins, adhesins, leukotoxin, superoxide dismutase, protectins, 
and hyaluronidase. Virulence genes like transferring-binding protein $\mathrm{A}(\operatorname{Tb} p A)$, leukotoxinC ( $(k t C)$, ferric-binding protein $\mathrm{A}(F b p A)$ which acquire similar properties to the transferrin, and several outer membrane proteins facilitate the development of the disease in the host [16] [17] [18]. Besides, M. haemolytica serotype-specific antigen (ssa) represents virulence-associated gene coding an important virulence marker responsible for the pathogenic potential of $M$. haemolytica [18] [19] [20]. Likewise, the Rpt2 locus (species-specific) modulates the type III restriction-modification system which acts as a barrier to the introduction of foreign DNA [21].

$P$. multocida possesses multiple virulence factors associated with fimbriae, capsule, polysaccharide, endotoxins, lipopolysaccharide (LPS), exotoxins, multocidins or siderophores, plasmids, outer membrane proteins (OMPs), and extracellular enzymes. The virulence-associated genes such as $\operatorname{tox} A, \operatorname{Tbp} A, \operatorname{sod} A$, sodC, $\operatorname{omp} A, \operatorname{ompH}$, and $p l p B$ play a significant role in the pathogenesis of the pathogen [15] [22] [23] [24]. P. multocida surface lipoproteins (pmSLP) are a class of soluble proteins that represent surface and are anchored to the outer membrane [25]. Hence, the identification of these virulence factors indicate the pathogenicity of bacterial pathogens.

Effective control of BRD is likely requires efficient intervention, definitive diagnosis, efficacious vaccines, therapeutic measures, and improved management practices [26]. Hence, BRD call for efficient controlling strategies. Thus, continuous outbreak surveillance and characterization of the major bacterial pathogens associated with BRD are essential for the development of an effective preventive approach. Moreover, molecular epidemiology is essential to determine the distribution of potential pathogenic serotypes circulating in the country. However, there are few studies on the characterization of $M$. haemolytica and $P$. multocida circulating in Ethiopia. Besides, information regarding serotypes and virulence genes distribution associated with BRD cases in cattle of Ethiopia is lacking. Therefore, the present study aimed to investigate BRD causing bacterial pathogens, distribution of capsular types, serotypes, and virulence-associated genes of M. haemolytica and P. multocida.

\section{Material and Methods}

\subsection{Sample Collection and Study Area}

Samples were collected from BRD outbreak cases, showing respiratory signs including depression, appetite loss, respiratory distress, high fever, nasal discharge, and lacrimation. 166 samples were collected from November 2020 to April 2021. Nasopharyngeal swab samples $(n=107)$ and a section of lung tissue samples $(n$ = 59) were excised from the pneumonic lungs. Samples were transported to the National Veterinary Institute (NVI), research and development laboratory, Ethiopia. Samples were collected from Hawassa, Ziway, and Mojo. Hawassa is located at $7^{\circ} 3^{\prime} 1.3464^{\prime \prime} \mathrm{N}$ and $38^{\circ} 29^{\prime} 43.8144 " \mathrm{E}$ with an elevation of 1712 meters above sea level (m.a.s.l). Ziway is located at $7^{\circ} 55^{\prime} 39.792^{\prime \prime} \mathrm{N}$ and $38^{\circ} 43^{\prime} 15.9888^{\prime \prime} \mathrm{E}$ 
at an altitude of 1645 m.a.s.l. Mojo is coordinated between $8^{\circ} 35^{\prime} 13.2648^{\prime \prime} \mathrm{N}$ and $39^{\circ} 7^{\prime} 23.3256^{\prime \prime} \mathrm{E}$ with an elevation of 1780 m.a.s.l.

\subsection{Isolation of Bacterial Pathogens}

Bacterial strains were isolated using the standard bacteriological assay. Briefly, pneumonic lung tissue samples were minced, reconstituted in $4 \mathrm{ml}$ sterile physiological saline $(\mathrm{pH} 7.0 \pm 0.2)$, centrifuged at $3000 \times \mathrm{g}$ for $3 \mathrm{~min}$, and the supernatant was discarded. The remaining sediment was reconstituted with $100 \mu \mathrm{l}$ sterile physiological saline. Ten $\mu$ l of pneumonic lung sample suspension and nasopharyngeal swabs were streaked comparably onto blood agar base (HiMedia, India) with $5 \%$ sheep blood and MacConkey agar (HiMedia, India). Plates were incubated at $37^{\circ} \mathrm{C}$ for $24-48$ hrs aerobically.

Colonies characteristics of Pasteurellaceae were further assayed as per the standard bacteriological method. Presumptive isolates were further analyzed using biochemical test (catalase and oxidase reaction, ornithine decarboxylase (ODC), indole production, nitrate reduction and urease). Identification of BRD-associated bacteria pathogens to species level was conducted using carbohydrate fermentation reaction (glucose, lactose, sucrose, arabinose, trehalose, dulcitol, mannitol, sorbitol, and D-xylose).

\subsection{Molecular Assay}

A PCR assay was conducted on presumptive bacterial pathogens of BRD as a confirmatory assay. Species-specific universal genes $R p t 2$ and $K m t 1$ were used for molecular detection of $M$. haemolytica and $P$. multocida, respectively. Genomic DNA was extracted using the Qiagen DNeasy Blood and Tissue Kit (QIAGEN GmbH, Germany) following the manufacturer's instruction.

\subsection{Serotyping}

Rabbit antisera were produced against $M$. haemolytica reference strains which were kindly provided by the NVI, Ethiopia. The assay was conducted using a rapid plate agglutination test against rabbit serum and classified to their respective serotypes [27]. Biotypes of $P$. multocida were assigned based on their sugar fermentation profiles [28].

\subsection{M. haemolytica and $P$. multocida Virulence-Associated Genes}

Virulence-associated genes detection was conducted using the PCR method on twenty-two randomly selected isolates of M. haemolytica $(n=11)$ and P. multocida $(n=11)$. PCR was conducted to investigate virulence-associated genes of $M$. haemolytica (ssa, sodA, FbpA, TbpA, and $1 k t C$ ) and P.multocida (toxA, FbpA, $T b p A$, and $p m S L P$ ) (Table 1 and Table 2).

\subsection{Electrophoresis}

Amplified PCR products were electrophoresed in 1.5\% agarose gels. PCR products $(10 \mu \mathrm{l})$ were mixed with loading buffer $(6 \times)$ and loaded into each separate 
Table 1. Primer pairs and PCR condition of virulence-associated genes.

\begin{tabular}{|c|c|c|c|c|c|c|}
\hline \multicolumn{4}{|c|}{$\begin{array}{l}\text { Isolates } \\
\text { virulence genes and function }\end{array}$} & Primer Sequence 5' - 3' & \multirow{2}{*}{$\begin{array}{l}\text { Size } \\
\text { (bp) }\end{array}$} & \multirow{2}{*}{$\begin{array}{l}\text { Reference } \\
\text { [3] [12] }\end{array}$} \\
\hline \multirow{6}{*}{ M. haemolytica } & $R p t 2$ & Species-specific & $\begin{array}{l}\mathrm{F} \\
\mathrm{R}\end{array}$ & $\begin{array}{l}\text { GTT TGT AAG ATA TCC CAT TT } \\
\text { CGT TTT CCA CTT GCG TGA }\end{array}$ & & \\
\hline & ssa & $\begin{array}{l}\text { Serotype-specific } \\
\text { surface antigen }\end{array}$ & $\begin{array}{l}\mathrm{F} \\
\mathrm{R}\end{array}$ & $\begin{array}{l}\text { TTC ACA TCT TCA TCC TC } \\
\text { TTT TCA TCC TCT TCG TC }\end{array}$ & 327 & [3] [12] \\
\hline & FbpA & Iron acquisition & $\begin{array}{l}\mathrm{F} \\
\mathrm{R}\end{array}$ & $\begin{array}{l}\text { GCA CTT GCT ATT GCT GCA G } \\
\text { CTC AGA GAA ATC GTC GAA }\end{array}$ & 1000 & This study \\
\hline & lktC & Toxin & $\begin{array}{l}\mathrm{F} \\
\mathrm{R}\end{array}$ & $\begin{array}{l}\text { GGA AAC ATT ACT TGG CTA TGG } \\
\text { TGT TGC CAG CTC TTC TTG ATA }\end{array}$ & 440 & [18] \\
\hline & $T b p A$ & Iron acquisition & $\begin{array}{l}\mathrm{F} \\
\mathrm{R}\end{array}$ & $\begin{array}{l}\text { TTTG GTT GGA AAC GGT AAA GC } \\
\text { TAA CGT GTA CGG AAA AGC CCC }\end{array}$ & 728 & {$[36]$} \\
\hline & $\operatorname{sod} A$ & $\begin{array}{l}\text { Superoxide } \\
\text { dismutase }\end{array}$ & $\begin{array}{l}\mathrm{F} \\
\mathrm{R}\end{array}$ & $\begin{array}{c}\text { GCC TGC GGA CAA ACG TGT TG } \\
\text { TTT CAA CAG AAC CAA AAT CAC GAA TG }\end{array}$ & 144 & [3] [24] \\
\hline \multirow{7}{*}{ P. multocida } & $K m t 1$ & Species-specific & $\begin{array}{l}\mathrm{F} \\
\mathrm{R}\end{array}$ & $\begin{array}{l}\text { ATC CGC TAT TTA CCC AGT GG } \\
\text { GCT GTA AAC GAA CTC GCC AC }\end{array}$ & 460 & [3] [12] [14] \\
\hline & tox $A$ & $\begin{array}{c}\text { Toxin } \\
\text { (dermonecrotoxin) }\end{array}$ & $\begin{array}{l}\mathrm{F} \\
\mathrm{R}\end{array}$ & $\begin{array}{l}\text { CTT AGA TGA GCG ACA AGG } \\
\text { GAA TGC CAC ACC TCT ATA G }\end{array}$ & 864 & {$[26]$} \\
\hline & $F b p A$ & Iron acquisition & $\begin{array}{l}\mathrm{F} \\
\mathrm{R}\end{array}$ & $\begin{array}{l}\text { GCA CTT GCT ATT GCT GCA G } \\
\text { CTC AGA GAA ATC GTC GAA }\end{array}$ & 500 & This study \\
\hline & $\begin{array}{c}\text { capA } \\
(\text { hyaD-hyaC) }\end{array}$ & Capsular synthesis & $\begin{array}{l}\mathrm{F} \\
\mathrm{R}\end{array}$ & $\begin{array}{l}\text { TGC CAA AAT CGC AGT CAG } \\
\text { TTG CCA TCA TTG TCA GTG }\end{array}$ & 1044 & [3] [13] \\
\hline & $\begin{array}{l}\text { capD } \\
(d c b F)\end{array}$ & Capsular synthesis & $\begin{array}{l}\mathrm{F} \\
\mathrm{R}\end{array}$ & $\begin{array}{l}\text { TTA CAA AAG AAA GAC TAG GAG CCC } \\
\text { CAT СТA ССС АСТ CAA CCA TAT CAG }\end{array}$ & 657 & [3] [13] \\
\hline & $T b p A$ & Iron acquisition & $\begin{array}{l}\mathrm{F} \\
\mathrm{R}\end{array}$ & $\begin{array}{l}\text { TTTG GTT GGA AAC GGT AAA GC } \\
\text { TAA CGT GTA CGG AAA AGC CCC }\end{array}$ & 728 & {$[36]$} \\
\hline & pmSLP & Surface lipoprotein & $\begin{array}{l}\mathrm{F} \\
\mathrm{R}\end{array}$ & $\begin{array}{c}\text { CCT CAC TCG CTC CGA CTA TT } \\
\text { TCA TCC CAA GTA AAA CCC AGT G }\end{array}$ & 1025 & This study \\
\hline
\end{tabular}

F: forward primer; R: reverse primer; bp: base pair.

wells. A $100 \mathrm{bp} / 1 \mathrm{~kb}$ plus DNA molecular marker was added into the first and last lane and run at $120 \mathrm{~V}$ for $60 \mathrm{~min}$. Products were visualized for the desired size of DNA bands under a gel documentation system (Uvitec, UK).

\subsection{Data Analysis}

Data were coded and stored in Excel and analyzed using statistical software (STATA 11). Descriptive statistics were used and statistical result was considered at $p<0.05$. 
Table 2. PCR condition of the different virulent gene primers.

\begin{tabular}{|c|c|c|c|c|c|}
\hline \multirow{2}{*}{$\begin{array}{l}\text { Virulence } \\
\text { genes }\end{array}$} & \multicolumn{5}{|c|}{$\begin{array}{c}\text { PCR condition } \\
\text { (Amplification } 35 \text { cycle) }\end{array}$} \\
\hline & $\begin{array}{c}\text { Primary } \\
\text { Denaturation }\end{array}$ & Denaturation & Annealing & Extension & $\begin{array}{c}\text { Final } \\
\text { extension }\end{array}$ \\
\hline$R p t 2$ & $95^{\circ} \mathrm{C} / 3 \mathrm{~min}$ & $95^{\circ} \mathrm{C} / 1 \mathrm{~min}$ & $48^{\circ} \mathrm{C} / 1 \mathrm{~min}$ & $72^{\circ} \mathrm{C} / 1 \mathrm{~min}$ & $72^{\circ} \mathrm{C} / 5 \mathrm{~min}$ \\
\hline ssa & $95^{\circ} \mathrm{C} / 3 \min$ & $95^{\circ} \mathrm{C} / 1 \mathrm{~min}$ & $48^{\circ} \mathrm{C} / 1 \mathrm{~min}$ & $72^{\circ} \mathrm{C} / 1 \mathrm{~min}$ & $72^{\circ} \mathrm{C} / 5 \mathrm{~min}$ \\
\hline$F b p A$ & $95^{\circ} \mathrm{C} / 5 \mathrm{~min}$ & $95^{\circ} \mathrm{C} / 30 \mathrm{~s}$ & $50^{\circ} \mathrm{C} / 30 \mathrm{~s}$ & $72^{\circ} \mathrm{C} / 1 \mathrm{~min}$ & $72^{\circ} \mathrm{C} / 7 \mathrm{~min}$ \\
\hline $1 k t C$ & $94^{\circ} \mathrm{C} / 5 \mathrm{~min}$ & $94^{\circ} \mathrm{C} / 30 \mathrm{~s}$ & $58^{\circ} \mathrm{C} / 40 \mathrm{~s}$ & $72^{\circ} \mathrm{C} / 40 \mathrm{~s}$ & $72^{\circ} \mathrm{C} / 10 \mathrm{~min}$ \\
\hline$T b p A$ & $95^{\circ} \mathrm{C} / 5 \mathrm{~min}$ & $95^{\circ} \mathrm{C} / 30 \mathrm{~s}$ & $50^{\circ} \mathrm{C} / 30 \mathrm{~s}$ & $72^{\circ} \mathrm{C} / 1 \mathrm{~min}$ & $72^{\circ} \mathrm{C} / 7 \mathrm{~min}$ \\
\hline $\operatorname{sod} A$ & $95^{\circ} \mathrm{C} / 5 \mathrm{~min}$ & $95^{\circ} \mathrm{C} / 30 \mathrm{~s}$ & $55^{\circ} \mathrm{C} / 30 \mathrm{~s}$ & $72^{\circ} \mathrm{C} / 40 \mathrm{~s}$ & $72^{\circ} \mathrm{C} / 5 \mathrm{~min}$ \\
\hline$K m t 1$ & $95^{\circ} \mathrm{C} / 5 \mathrm{~min}$ & $95^{\circ} \mathrm{C} / 45 \mathrm{~s}$ & $55^{\circ} \mathrm{C} / 1 \mathrm{~min}$ & $72^{\circ} \mathrm{C} / 1 \mathrm{~min}$ & $72^{\circ} \mathrm{C} / 10 \mathrm{~min}$ \\
\hline tox $A$ & $94^{\circ} \mathrm{C} / 5 \mathrm{~min}$ & $94^{\circ} \mathrm{C} / 30 \mathrm{~s}$ & $48^{\circ} \mathrm{C} / 40 \mathrm{~s}$ & $72^{\circ} \mathrm{C} / 45 \mathrm{~s}$ & $72^{\circ} \mathrm{C} / 10 \mathrm{~min}$ \\
\hline hyaD-hyaC & $95^{\circ} \mathrm{C} / 5 \mathrm{~min}$ & $95^{\circ} \mathrm{C} / 1 \mathrm{~min}$ & $55^{\circ} \mathrm{C} / 1 \mathrm{~min}$ & $72^{\circ} \mathrm{C} / 1: 30 \mathrm{~s}$ & $72^{\circ} \mathrm{C} / 7 \mathrm{~min}$ \\
\hline$d c b F$ & $94^{\circ} \mathrm{C} / 5 \mathrm{~min}$ & $94^{\circ} \mathrm{C} / 1 \mathrm{~min}$ & $55^{\circ} \mathrm{C} / 1 \mathrm{~min}$ & $72^{\circ} \mathrm{C} / 30 \mathrm{~s}$ & $72^{\circ} \mathrm{C} / 7 \mathrm{~min}$ \\
\hline pmSLP & $94^{\circ} \mathrm{C} / 2 \mathrm{~min}$ & $94^{\circ} \mathrm{C} / 15 \mathrm{~s}$ & $62^{\circ} \mathrm{C} / 30 \mathrm{~s}$ & $68^{\circ} \mathrm{C} / 1 \mathrm{~min}$ & $68^{\circ} \mathrm{C} / 5 \min$ \\
\hline
\end{tabular}

\section{Results}

\subsection{Outbreak Investigation}

Diseased animals showed high fever $\left(>40.0^{\circ} \mathrm{C}\right)$, coughing, anorexia, severe respiratory distress, marked depression, salivation, and absence of rales when the ventral lung auscultated. Infected animals appeared dull and respiratory grunts were observed in advanced cases. Cattle slaughtered at the abattoir were inspected for typical gross pathological lesions. The affected parts of the lung showed firm, friable, irregularity in shape, consolidation, and dark red coloration were frequently observed in pneumonic cases. In some advanced cases, pulmonary parenchymal consolidation and interstitial edema were evidenced.

\subsection{Biochemical Characterization}

Bacterial pathogens isolated from nasopharyngeal and pneumonic lung samples of cattle revealed the identification of M. haemolytica, P. multocida, B. trehalosi, and H. somni. Isolates were Gram-negative, coccobacilli, and pleomorphic (Table 3).

\subsection{Isolation of Bacterial Pathogens}

Bacteriological assay showed that $37(22.29 \%)$ M. haemolytica isolates and 26 (15.66\%) P. multocida isolates were identified. Besides, 12 (7.23\%) B. trehalosi isolates and $15(9.04 \%) H$. somni isolates were phenotypically characterized from outbreak samples at $p>0.05$ (Table 4). 
Table 3. Biochemical profile of presumptive isolates.

\begin{tabular}{|c|c|c|c|c|c|c|c|c|c|c|c|c|c|c|c|}
\hline \multirow[b]{2}{*}{ Isolates } & \multicolumn{15}{|c|}{ Biochemical assay } \\
\hline & 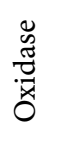 & 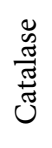 & 仓̊ & $\begin{array}{l}\frac{0}{0} \\
\frac{\pi}{\Xi}\end{array}$ & 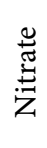 & 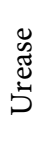 & $\begin{array}{l}\mathscr{O} \\
\stackrel{0}{0} \\
\stackrel{0}{J}\end{array}$ & 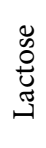 & 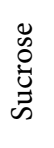 & 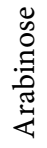 & 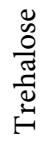 & $\begin{array}{l}\overrightarrow{0} \\
\stackrel{0}{0} \\
\vec{\Xi} \\
0\end{array}$ & 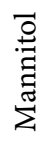 & $\begin{array}{l}\overrightarrow{0} \\
.0 \\
0 \\
0 \\
0 \\
\infty\end{array}$ & 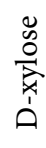 \\
\hline M. haemolytica & $+^{*}$ & + & $-* *$ & - & + & - & + & + & + & + & - & - & + & + & + \\
\hline P. multocida & + & + & + & + & + & - & + & - & + & - & - & - & + & + & + \\
\hline B. trehalosi & + & + & - & - & + & - & + & - & + & - & + & - & + & + & + \\
\hline H. somni & + & - & + & + & + & - & + & - & + & - & + & + & + & + & + \\
\hline
\end{tabular}

${ }^{*}+$ : Positive; ${ }^{* *}-$ negative.

Table 4. Prevalence of bacterial pathogens.

\begin{tabular}{cccccc}
\hline \multirow{2}{*}{ Isolates } & \multicolumn{5}{c}{ Study area and sample size } \\
\cline { 2 - 6 } & $\begin{array}{c}\text { Hawassa } \\
(n=67)\end{array}$ & $\begin{array}{c}\text { Ziway } \\
(n=37)\end{array}$ & $\begin{array}{c}\text { Mojo } \\
(n=62)\end{array}$ & $\begin{array}{c}\text { Total } \\
(n=166)\end{array}$ & $\begin{array}{c}\text { Chi-square } \\
\text { test }\end{array}$ \\
\hline M. haemolytica & $14(20.89 \%)$ & $13(35.13 \%)$ & $10(16.13 \%)$ & $37(22.29 \%)$ & \\
P. multocida & $11(16.42 \%)$ & $9(24.32 \%)$ & $5(8.06 \%)$ & $25(15.06 \%)$ & $0.648^{*}$ \\
B. trehalosi & $5(7.46 \%)$ & $6(16.22 \%)$ & $1(1.61 \%)$ & $12(7.23 \%)$ & \\
H. somni & $7(10.45 \%)$ & $7(18.92 \%)$ & $1(1.61 \%$ & $15(9.04 \%)$ & \\
\hline
\end{tabular}

*The result is not significant at $p<0.05$.

\subsection{PCR Assay}

PCR assay confirmed that all (100\%) M. haemolytica isolates and 25 (96.15\%) $P$. multocida isolates were positive for the Rpt2 and kmt1 universal genes, respectively. Besides, all $B$. trehalosi isolates were found positive for the $\operatorname{sod} A$ gene. Capsular typing of $P$. multocida isolates posive for $k m t 1$ gene revealed that 21 $(84.0 \%)$ isolates were belonged to capsular type A (hyaD-hyaC) and $4(16.0 \%)$ were belonged capsular type $\mathrm{D}(d c b F)$ (Figure 1$)$.

\subsection{Serotyping and Biotying}

Serotyping of Rpt2 PCR-positive $M$. haemolytica isolates revealed that $26(70.27 \%)$ isolates were belonged to serotype A: 1, 4 (10.81\%) isolates were serotype A: 2, and 7 (18.92\%) were belonged to $M$. haemolytica serotype A: 6. P. multocida kmt1 and hyaD-hyaC PCR-positive isolates belonged to biotype A: 1, A: 2, and A: 3 from 3 (14.29\%), 2 (9.52\%), and $16(76.19 \%)$ isolates, respectively.

\subsection{Virulence Gene Detection}

M. haemolytica strains harbored ssa in 7 (63.63\%) and sodA in $10(90.91 \%)$ strains, while $F b p A, T b p A$, and $l k t C$ genes were found in all isolates. P. multocida exhibited 100\% tox $A, F b p A, T b p A$, and $p m S L P$ genes (Table 5 and Figure 2). 


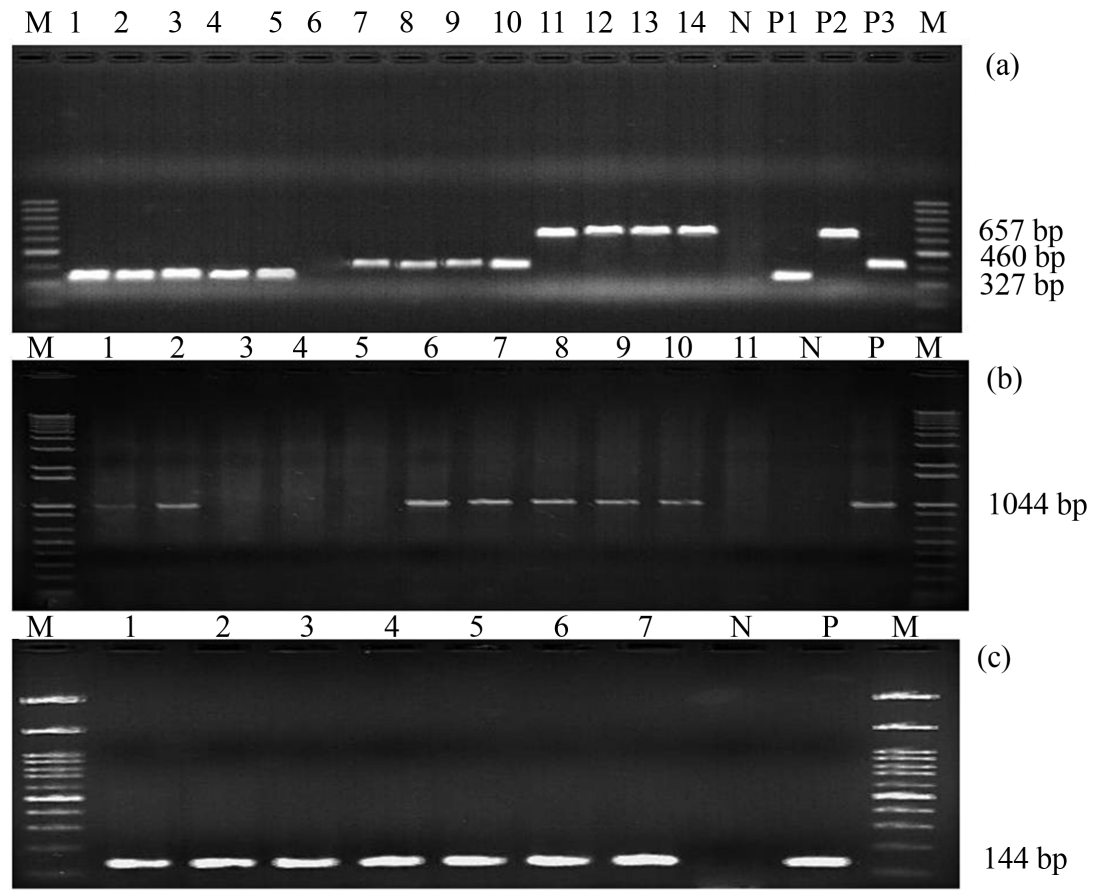

Figure 1. Agarose gel electrophoresis (a) (lane M: molecular ladder; lane 1 - 5: M. haemolytica ssa gene (327 bp); lane 7 - 10: P. multocida kmt1 gene (460 bp); lane 11 - 14: $P$. multocida capsular type D (657 bp); lane N: negative control; lane P1 - P3: positive control); (b) P. multocida capsular type A (1044 bp); (c) B. trehalosi isolates sodA gene (144 bp).

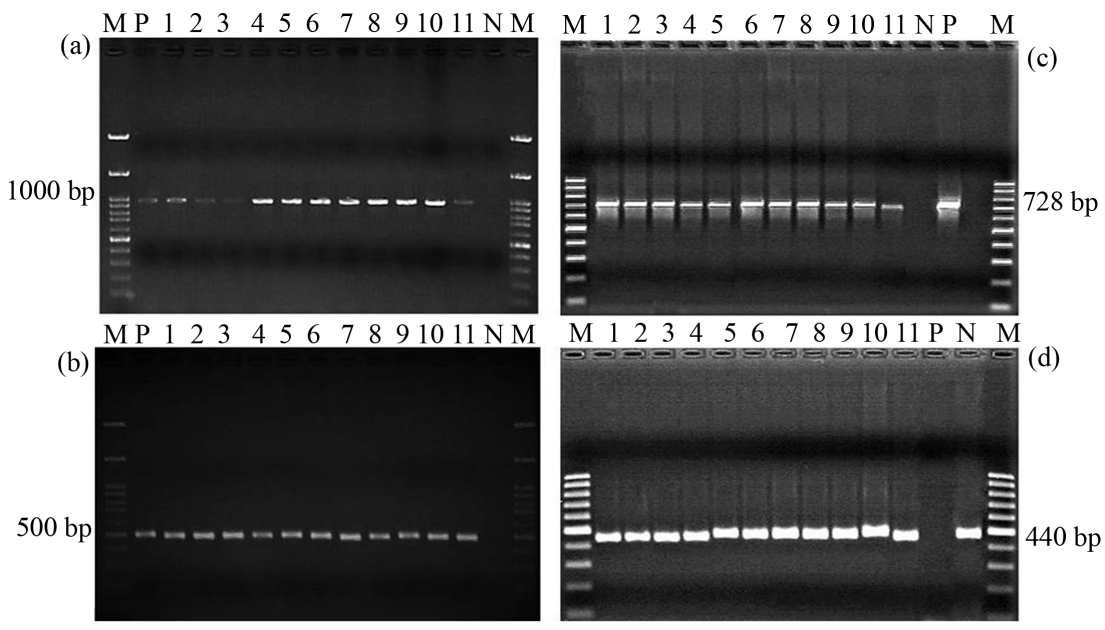

Figure 2. Agarose gel electrophoresis of Virulence-associated genes (a) $F b p A$ gene of $M$. haemolytica (1000 bp); (b) FbpA gene of P. multocida (500 bp); (c) TbpA gene of P. multocida (728 bp); (d) IktC gene of M. haemolytica (440 bp).

\section{Discussion}

$\mathrm{BRD}$ is a multiplex illness that causes a severe form of pneumonia in all age groups of cattle. It is caused by range of factors such as multiple bacterial and viral pathogens together with environmental stressors are responsible for the outbreak of this disease [29]. BRD infected animals are detected late or not detected 
Table 5. Virulence genes detected in M. haemolytica and P. multocida.

\begin{tabular}{|c|c|c|c|c|c|}
\hline \multirow{2}{*}{ Isolates } & \multirow{2}{*}{ Virulence gene } & \multicolumn{4}{|c|}{ Isolates } \\
\hline & & Positive & $\%$ & Negative & $\%$ \\
\hline \multirow{5}{*}{$\begin{array}{c}\text { M. haemolytica } \\
\quad(n=11)\end{array}$} & Ssa & 7 & 63.64 & 4 & 36.36 \\
\hline & Soda & 10 & 90.91 & 1 & 9.09 \\
\hline & $F b p A$ & 11 & 100 & 0 & 0 \\
\hline & $T b p A$ & 11 & 100 & 0 & 0 \\
\hline & $1 k t C$ & 11 & 100 & 0 & 0 \\
\hline \multirow{4}{*}{$\begin{array}{c}\text { P. multocida } \\
(n=11)\end{array}$} & tox $A$ & 11 & 100 & 0 & 0 \\
\hline & $F b p A$ & 11 & 100 & 0 & 0 \\
\hline & $\operatorname{Tbp} A$ & 11 & 100 & 0 & 0 \\
\hline & $p m S L P$ & 11 & 100 & 0 & 0 \\
\hline
\end{tabular}

at all during the disease development. Hence, early intervention is essential to effectively control the disease and reduce morbidity and mortality. Besides, compiling the prevalence of the major causative pathogens of BRD might help in early intervention and disease control [30] [31]. Therefore, outbreak monitoring, investigation, and identification of bacterial pathogens are significant to design effective controlling strategies.

BRD outbreak investigation aids in defining the frequency of the major infectious pathogens. The clinical signs observed in the current study include coughing, depression, loss of appetite, respiratory distress, and elevated temperature (DART). These findings are consistent with previous studies [7] [8]. Pneumonic lung gross pathological lesion inspection showed irregularity in shape, dark red coloration, marbling, non-friable foci, or fibrinous pleuritis, pulmonary parenchymal consolidation, and interstitial edema in advanced cases were consistent with previous findings [7] [30] [32]. However, diagnosis of BRD infection based on clinical symptoms is difficult. Consequently, diagnosis has to be supported with the identification of the exact pathogens.

In the current outbreak investigation, bacteriological assay revealed higher prevalence of M. haemolytica 37 (22.29\%) followed by P. multocida 25 (15.06\%). Besides, H. somni and B. trehalosi are identified from 15 (9.04\%) and 12 (7.23\%) outbreak samples, respectively. This study showed the potential impact of $M$. haemolytica and P. multocida in the study areas. The current finding indicated a lower prevalence of $M$. haemolytica as compared to previous reports of $50.59 \%$ [3], 46.4\% [4] and 29.2\% [33]. However, it is higher than other reports of $10.67 \%$ and $10.13 \%$ of $M$. haemolytica from the central part of the country [34] [35]. Alike, $14.3 \%$ and $12.67 \%$ B. trehalosi incidence was reported in previous studies [4] [33]. Therefore, this study highlights the significant role of $M$. haemolytica, B. trehalosi, P. multocida, and H. somni in causing BRD outbreaks.

PCR assay designed to amplify the $r p t 2$ locus (species-specific) universal gene 
of $M$. haemolytica used as a confirmatory assay [18] [21]. Besides, primers targeting fragment of the $k m t 1$ gene of $P$. multocida produce unique amplification product to all strains [12] [14]. The PCR result of $M$. haemolytica and P. multocida isolates using the rpt2 and kmt universal genes confirmed $37(100 \%)$ and 25 (96.15\%) of M. haemolytica and P. multocida isolates, respectively. PCR results of M. haemolytica and P. multocida using the universal primers $r p t 2$ and $k m t 1$ are in agreement with the previous findings in Ethiopia from pneumonic cattle and sheep [3] [12]. Besides, the PCR assay designed to detect $P$. multocida capsular type A and D strains using specific cap loci (hyaD-hyaC) and $(d c b F)$ genes, respectively [13]. The capsular typing revealed 21 (84.0\%) capsular type A (hyaD-hyaC) and $4(16.0 \%)$ capsular type $\mathrm{D}(d c b F)$. These findings are in accordance with previous reports [36] [37] and these studies have proved that $P$. multocida (capsular type A) isolates are the principal causative agent of BRD [38] [39].

Serotyping of PCR positive $M$. haemolytica $(n=37)$ showed that $70.27 \%$ isolates belonged to serotype A: $1,10.81 \%$ serotype A: 2 , and $18.92 \%$ belonged to serotype A: 6 . Higher prevalence of $M$. haemolytica serotype A: 1 and distribution of serotype A: 2 and A: 6 in the present study was agreed with other reports who identified these serotypes from cattle suffering from BRD [3] [16] [26]. Besides, biotyping of $P$. multocida $(n=21)$ strains indicated that $76.19 \%$ isolates were A: 3 , while $14.29 \%$ and $9.52 \%$ were belonged to A: 1 and A: 2, respectively. Higher prevalence of $P$. multocida A: 3 in the present study was in agreement with previous reports [37] [39].

In the present study, PCR based assay confirmed the distribution of virulence-associated genes. Potential virulence factors of $M$. haemolytica include ssa, $\operatorname{sod} A, F b p A, T b p A$, and $1 k t C$. Among these virulence-associated genes, Lkt is important in inducing pneumonia. The findings revealed that $M$. haemolytica isolates harbored $100 \% F b p A, T b p A$, and $l k t C$ genes while the ssa gene was identified from $63.64 \%$ and sod $A$ gene from $90.91 \%$ strains. PCR assay results of M. haemolytica are comparable to previous findings, who reported lktC as species-specific in most M. haemolytica isolates [16] [17]. Besides, ssa gene of serotype-specific antigen of outer membrane protein serine protease is considered as the most important virulence factor in $M$. haemolytica isolates [29].

P. multocida isolates exhibited toxA, FbpA, TbpA, and $p m S L P$ in all isolates. These virulence genes play important roles in the pathogenesis of BRD [15] [23] [26]. The gene encoding dermonecrotoxin (tox $A$ ) defines the pathogenic potential of $P$. multocida strains. This virulence gene is responsible for the clinical symptoms associated with pneumonia [15] [23] [39]. Higher prevalence of TbpA was reported in isolates from diseased cattle [20] [36]. Besides, the surface lipoprotein (SLP) of $P$. multocida is essential for host colonization [40] and the FbpA gene possess similar properties with transferrins and has a great role in transporting and removing iron across the outer membrane [41]. Hence, among these virulence genes the tox $A$ and $t p b A$ genes of $P$. multocida are important epidemiological gene markers [26] [42]. Identification of virulence genes implies sig- 
nificant information about the pathogenicity of $M$. haemolytica and $P$. multocida isolates.

\section{Conclusion}

In conclusion, remarkable evidence was identified in the distribution of capsular type, serotypes, and virulence-associated genes of $M$. haemolytica and $P$. multocida. PCR assay indicated that $M$. haemolytica (A: 1) and P. multocida (A: 3) were the most prevalent isolates to cause BRD. Detection of virulence genes of M. haemolytica (ssa, sodA, FbpA, TbpA, and lktC) and P. multocida (toxA, $F b p A, T b p A$, and $p m S L P$ ) in most of the strains implies the pathogenic potential of both pathogens to cause disease outbreak. Hence, the current findings provide relevant information to understand the capsular types, serotypes, and virulence gene incidence associated with $M$. haemolytica and $P$. multocida. Therefore, continuous outbreak surveillance from wider areas of the country and molecular epidemiology are indispensable in designing efficient prevention strategies.

\section{Acknowledgements}

The authors are grateful to acknowledge the Research and Development Laboratories (NVI, Ethiopia) for allowing the laboratory facility to conduct this research. Great appreciation was forwarded to Veterinary clinics located in the study areas, animal owners, and abattoir staff for their cooperation during sample collection. The authors also thank the Department of Biotechnology, Koneru Lakshmaiah Education Foundation (KLEF) for supporting the study.

\section{Data Availability}

All data supporting the findings of this study can be obtained from the corresponding author upon formal request.

\section{Ethical Consideration}

Consent was first obtained from animal owners. Samples collection followed scientific protocols and animal handling employed with basic animal welfare ethics. Laboratory assay was executed following the standard bacteriological and molecular methods.

\section{Conflicts of Interest}

Authors declare that they have no conflict of interests.

\section{References}

[1] Shapiro, B.I., Getachew, G., Solomon, D., Asfaw, N., Kidus, N., Gezahegn, A. and Henok, M. (2017) Ethiopia Livestock Sector Analysis: A 15 Year Livestock Sector Strategy. International Livestock Research Institute, Nairobi. https://cgspace.cgiar.org/bitstream/handle/10568/92057/LSA_Ethiopia.pdf

[2] Central Statistical Agency (CSA) (2017) Federal Democratic Republic of Ethiopia: 
Agricultural Sample Survey 2016/17 Volume-2: Report on Livestock and Livestock Characteristics (Private Peasant Holdings). Statistical Bulletin No. 585, Central Statistical Agency, Addis Ababa.

[3] Akalu, M., Murthy, B., Abayeneh, T. and Gelaye, E. (2021) Major Bacterial Pathogens of Bovine Respiratory Disease and Lung Lesions in Calves from Selected Areas of Ethiopia. The Thai Journal of Veterinary Medicine, 51, 501-508.

[4] Abera, D., Sisay, T. and Birhanu, T. (2014) Isolation and Identification of Mannhemia and Pasturella Species from Pneumonic and Apparently Healthy Cattle and Their Antibiogram Susceptibility Pattern in Bedelle District, Western Ethiopia. African Journal of Bacteriology Research, 6, 32-41.

[5] Murray, G.M., More, S.J., Clegg, T.A., Earley, B., O’Neill, R.G., Johnston, D. and Cassidy, J.P. (2018) Risk Factors Associated with Exposure to Bovine Respiratory Disease Pathogens during the Peri-Weaning Period in Dairy Bull Calves. BMC Veterinary Research, 14, Article No. 53. https://doi.org/10.1186/s12917-018-1372-9

[6] Delabouglise, A., James, A., Valarcher, J.F., Hagglünd, S., Raboisson, D. and Rushton, J. (2017) Linking Disease Epidemiology and Livestock Productivity: The Case of Bovine Respiratory Disease in France. PLoS ONE, 12, Article ID: e0189090. https://doi.org/10.1371/journal.pone.0189090

[7] Peek, S.F., Ollivett, T.L. and Divers, T.J. (2018) Respiratory Diseases. In: Peek, S.F. and Divers, T.J., Eds., Rebhun's Diseases of Dairy Cattle, Saunders, Philadelphia, 94-167. https://doi.org/10.1016/B978-0-323-39055-2.00004-8

[8] Griffin, D., Chengappa, M.M., Kuszak, J. and McVey, D.S. (2010) Bacterial Pathogens of the Bovine Respiratory Disease Complex. Veterinary Clinics of North America: Food Animal Practice, 26, 381-394. https://doi.org/10.1016/j.cvfa.2010.04.004

[9] Confer, A.W. and Ayalew, S. (2018) Mannheimia haemolytica in Bovine Respiratory Disease: Immunogens, Potential Immunogens, and Vaccines. Animal Health Research Reviews, 19, 79-99. https://doi.org/10.1017/S1466252318000142

[10] Murugananthan, A., Shanthalingam, S., Batra, S.A., Alahan, S. and Srikumaran, S. (2018) Leukotoxin of Bibersteinia trehalosi Contains a Unique Neutralizing Epitope, and a Non-Neutralizing Epitope Shared with Mannheimia haemolytica Leukotoxin. Toxins, 10, Article No. 220. https://doi.org/10.3390/toxins10060220

[11] Haig, S.J. (2011) Adherence of Mannheimia haemolytica to Ovine Bronchial Epithelial Cells. Bioscience Horizons, 4, 50-60. https://doi.org/10.1093/biohorizons/hzr007

[12] Legesse, A., Abayneh, T., Mamo, G., Gelaye, E., Tesfaw, L., Yami, M. and Belay, A. (2018) Molecular Characterization of Mannheimia haemolytica Isolates Associated with Pneumonic Cases of Sheep in Selected Areas of Central Ethiopia. BMC Microbiology, 18, Article No. 50. https://doi.org/10.1186/s12866-018-1338-x

[13] Townsend, K.M., Boyce, J.D., Chung, J.Y., Frost, A.J. and Adler, B. (2001) Genetic Organization of Pasteurella multocida Cap Loci and Development of a Multiplex Capsular PCR Typing System. Journal of Clinical Microbiology, 39, 924-929. https://doi.org/10.1128/JCM.39.3.924-929.2001

[14] Townsend, K.M., Frost, A.J., Lee, C.W., Papadimitriou, J.M. and Dawkins, H.J. (1998) Development of PCR Assays for Species- and Type-Specific Identification of Pasteurella multocida Isolates. Journal of Clinical Microbiology, 36, 1096-1100. https://doi.org/10.1128/JCM.36.4.1096-1100.1998

[15] Harper, M., Boyce, J.D. and Adler, B. (2006) Pasteurella multocida Pathogenesis: 125 Years after Pasteur. FEMS Microbiology Letters, 265, 1-10. https://doi.org/10.1111/j.1574-6968.2006.00442.x 
[16] Singh, K., Ritchey, J.W. and Confer, A.W. (2011) Mannheimia haemolytica: Bacterial-Host Interactions in Bovine Pneumonia. Veterinary Pathology, 48, 338-348. https://doi.org/10.1177/0300985810377182

[17] Klima, C.L., Zaheer, R., Cook, S.R., Booker, C.W., Hendrick, S., Alexander, T.W. and McAllister, T.A. (2014) Pathogens of Bovine Respiratory Disease in North American Feedlots Conferring Multidrug Resistance via Integrative Conjugative Elements. Journal of Clinical Microbiology, 52, 438-448.

https://doi.org/10.1128/JCM.02485-13

[18] Abed, A.H., El-Seedy, F.R., Hassan, H.M., Nabih, A.M., Khalifa, E., Salem, S.E. and Menshawy, A. (2020) Serotyping, Genotyping and Virulence Genes Characterization of Pasteurella multocida and Mannheimia haemolytica Isolates Recovered from Pneumonic Cattle Calves in North Upper Egypt. Veterinary Sciences, 7, Article No. 174. https://doi.org/10.3390/vetsci7040174

[19] Adhikari, P., Kirby, S.D., Nowalk, A.J., Veraldi, K.L., Schryvers, A.B. and Mietzner, T.A. (1995) Biochemical Characterization of a Haemophilus influenzae Periplasmic Iron Transport Operon. Journal of Biological Chemistry, 270, 25142-25149. https://doi.org/10.1074/jbc.270.42.25142

[20] Shouldice, S.R., McRee, D.E., Dougan, D.R., Tari, L.W. and Schryvers, A.B. (2005) Novel Anion-Independent Iron Coordination by Members of a Third Class of Bacterial Periplasmic Ferric Ion-Binding Proteins. Journal of Biological Chemistry, 280, 5820-5827. https://doi.org/10.1074/jbc.M411238200

[21] Ryan, K.A. and Lo, R.Y. (1999) Characterization of a CACAG Pentanucleotide Repeat in Pasteurella haemolytica and Its Possible Role in Modulation of a Novel Type III Restriction-Modification System. Nucleic Acids Research, 27, 1505-1511. https://doi.org/10.1093/nar/27.6.1505

[22] Katsuda, K., Hoshinoo, K., Ueno, Y., Kohmoto, M. and Mikami, O. (2013) Virulence Genes and Antimicrobial Susceptibility in Pasteurella multocida Isolates from Calves. Veterinary microbiology, 167, 737-741.

https://doi.org/10.1016/j.vetmic.2013.09.029

[23] Verma, S., Sharma, M., Katoch, S., Verma, L., Kumar, S., Dogra, V. and Singh, G. (2013) Profiling of Virulence Associated Genes of Pasteurella multocida Isolated from Cattle. Veterinary Research Communications, 37, 83-89. https://doi.org/10.1007/s11259-012-9539-5

[24] Dassanayake, R.P., Call, D.R., Sawant, A.A., Casavant, N.C., Weiser, G.C., Knowles, D.P. and Srikumaran, S. (2010) Bibersteinia trehalosi Inhibits the Growth of Mannheimia haemolytica by a Proximity-Dependent Mechanism. Applied and Environmental Microbiology, 76, 1008-1013. https://doi.org/10.1128/AEM.02086-09

[25] Wilson, M.M. and Bernstein, H.D. (2016) Surface-Exposed Lipoproteins: An Emerging Secretion Phenomenon in Gram-Negative Bacteria. Trends in Microbiology, 24, 198-208. https://doi.org/10.1016/j.tim.2015.11.006

[26] Rice, J.A., Carrasco-Medina, L., Hodgins, D.C. and Shewen, P.E. (2007) Mannheimia haemolytica and Bovine Respiratory Disease. Animal Health Research Reviews, 8, 117-128. https://doi.org/10.1017/S1466252307001375

[27] Klima, C.L., Zaheer, R., Briggs, R.E. and McAllister, T.A. (2017) A Multiplex PCR Assay for Molecular Capsular Serotyping of Mannheimia haemolytica Serotypes 1, 2, and 6. Journal of Microbiological Methods, 139, 155-160. https://doi.org/10.1016/j.mimet.2017.05.010

[28] Kim, J., Kim, J.W., Oh, S.I., So, B., Kim, W.I. and Kim, H.Y. (2019) Characterisation of Pasteurella multocida Isolates from Pigs with Pneumonia in Korea. BMC Veteri- 
nary Research, 15, Article No. 119. https://doi.org/10.1186/s12917-019-1861-5

[29] Klima, C.L., Holman, D.B., Ralston, B.J., Stanford, K., Zaheer, R., Alexander, T.W. and McAllister, T.A. (2019) Lower Respiratory Tract Microbiome and Resistome of Bovine Respiratory Disease Mortalities. Microbial Ecology, 78, 446-456. https://doi.org/10.1007/s00248-019-01361-3

[30] Timsit, E., Bareille, N., Seegers, H., Lehébel, A. and Assie, S. (2011) Visually Undetected Fever Episodes in Newly Received Beef Bulls at a Fattening Operation: Occurrence, Duration, and Impact on Performance. Journal of Animal Science, 89, 4272-4280. https://doi.org/10.2527/jas.2011-3892

[31] Allen, J.W., Viel, L., Bateman, K.G., Rosendal, S., Shewen, P.E. and Physick-Sheard, P. (1991) The Microbial Flora of the Respiratory Tract in Feedlot Calves: Associations between Nasopharyngeal and Bronchoalveolar Lavage Cultures. Canadian Journal of Veterinary Research, 55, 341-346.

[32] Caswell, J.L., Hewson, J., Slavić, Đ., DeLay, J. and Bateman, K. (2012) Laboratory and Postmortem Diagnosis of Bovine Respiratory Disease. Veterinary Clinics: Food Animal Practice, 28, 419-441. https://doi.org/10.1016/j.cvfa.2012.07.004

[33] Musteria M, Getnet F, Anteneh W, and Yehualashet B., (2017) Isolation of Pasteurella multocida and Mannheimia hemolytica from Pneumonic Calves and Their Antibiotic Susceptibility in Harar and Haramaya, Eastern Ethiopia. Global Veterinaria, 19, 627-632.

[34] Mebratu, A., Habtamu, B. and Melkamu, B. (2015) Isolation and Characterization of Respiratory Tract Bacterial Species from Domestic Animals with Pneumonic Lungs from Elphora Abattoir, Ethiopia. International Journal of Microbiological Research, 6, 13-19.

[35] Gebremeskel, A.K., Tesema, T.S., Yegoraw, A.A., Birhanu, B.T. and Mekuria, S.A. (2017) Isolation and Characterization of Bacterial Species from Respiratory Tracts of Cattle Slaughtered in Addis Ababa City, Central Ethiopia. World Veterinary Journal, 7, 14-20.

[36] Aski, H.S. and Tabatabaei, M. (2016) Occurrence of Virulence-Associated Genes in Pasteurella multocida Isolates Obtained from Different Hosts. Microbial Pathogenesis, 96, 52-57. https://doi.org/10.1016/j.micpath.2016.04.008

[37] Mirtneh, Y.A., Vemulapati, B.M., Takele, A., Martha, Y., Teferi, D., Alebachew, B. and Esayas, G., (2021) Phenotypic and Molecular Characterization of the Capsular Serotypes of Pasteurella multocida Isolated from Pneumonic Cases of Cattle in Ethiopia. Agricultural Science Digest, Article ID: D-333. https://doi.org/10.18805/ag.D-333

[38] Ewers, C., Lübke-Becker, A., Bethe, A., Kießling, S., Filter, M. and Wieler, L.H. (2006) Virulence Genotype of Pasteurella multocida Strains Isolated from Different Hosts with Various Disease Status. Veterinary Microbiology, 114, 304-317. https://doi.org/10.1016/j.vetmic.2005.12.012

[39] Dabo, S.M., Taylor, J.D. and Confer, A.W. (2007) Pasteurella multocida and Bovine Respiratory Disease. Animal Health Research Reviews, 8, 129-150. https://doi.org/10.1017/S1466252307001399

[40] Hooda, Y., Lai, C.C. and Moraes, T.F. (2017) Identification of a Large Family of Slam-Dependent Surface Lipoproteins in Gram-Negative Bacteria. Frontiers in Cellular and Infection Microbiology, 7, Article No. 207. https://doi.org/10.3389/fcimb.2017.00207

[41] Khan, A.G., Shouldice, S.R., Kirby, S.D., Yu, R.H., Tari, L.W. and Schryvers, A.B. (2007) High-Affinity Binding by the Periplasmic Iron-Binding Protein from Hae- 
mophilus influenzae is Required for Acquiring Iron from Transferrin. Biochemical Journal, 404, 217-225. https://doi.org/10.1042/BJ20070110

[42] Devi, L.B., Bora, D.P., Das, S.K., Sharma, R.K., Mukherjee, S. and Hazarika, R.A. (2018) Virulence Gene Profiling of Porcine Pasteurella multocida Isolates of Assam. Veterinary World, 11, 348-354. https://doi.org/10.14202/vetworld.2018.348-354

\section{List of Abbreviations}

BRD: Bovine Respiratory Disease; FbpA: Ferric-binding protein A; LPS: Lipopolysaccharide; lktC: leukotoxinC; pmSLP: P. multocida surface lipoproteins; PCR: Polymerase Chain Reaction; TbpA: Transferring-binding protein A; ssa: $M$. haemolytica serotype-specific antigen. 